\title{
ATYPICAL INTRACRANIAL CALCIFICATIONS IN A CONVENTIONAL RADIOGRAPHIC EXAM
}

\author{
Marília Sfredo Kruger ${ }^{1}$, Amália Isaura Medeiros Klaes¹, \\ Ana Claudia de Souza ${ }^{1}$, Andréia Wallau Vilaverde ${ }^{1}$, \\ Antonio Carlos Maciel', Dorvaldo Paulo Tarasconi', \\ Juliana Ávila Duarte ${ }^{1}$, Leonardo Modesti Vedolin ${ }^{1}$
}

Clin Biomed Res. 2014;34(4):412-413

1 Serviço de Radiologia, Hospital de Clínicas de Porto Alegre. Porto Alegre, RS, Brazil.

Corresponding author: Juliana Ávila Duarte

E-mail: juavila2003@yahoo.com.br Serviço de Radiologia Hospital de Clínicas de Porto Alegre Rua Ramiro Barcelos, 2350. 90035-903, Porto Alegre, RS, Brazil.
An 18-year-old male patient of consanguineous parents, delivered at full-term by cesarean section and having no changes in neurodevelopment, presented with skin blisters that evolved to eruptions and scars immediately after birth. In childhood, he developed lesions and diffuse tongue hypertrophy, with cutaneous hyperkeratosis and periods of exacerbation after sun exposure or trauma. In regular outpatient appointments with the medical assistant team, neurological symptoms were not observed. He underwent surgery because of an obstruction of the salivary duct with local abscess. A biopsy of skin lesion was performed and its histological analysis suggested lipoid proteinosis.

Skull radiographic examination demonstrated bilateral and symmetrical parasellar radiodense foci showing a regular structure (figure 1). Analysis of clinical and histological data together with shape and localization of intracranial calcifications is compatible with the presence of amygdalae (figure 1) calcifications, confirming the histological diagnosis (figure 2).

Lipoid proteinosis, also known as Urbach-Wiethe disease, is an autosomal recessive genodermatosis caused by mutations in the ECM1 gene ${ }^{1}$ and clinically characterized by mucocutaneous lesions, moniliform blepharosis, hoarse voice, and thick short sublingual frenulum that restrict the movement of the tongue ${ }^{1-5}$. Laboratory findings are not specific'.
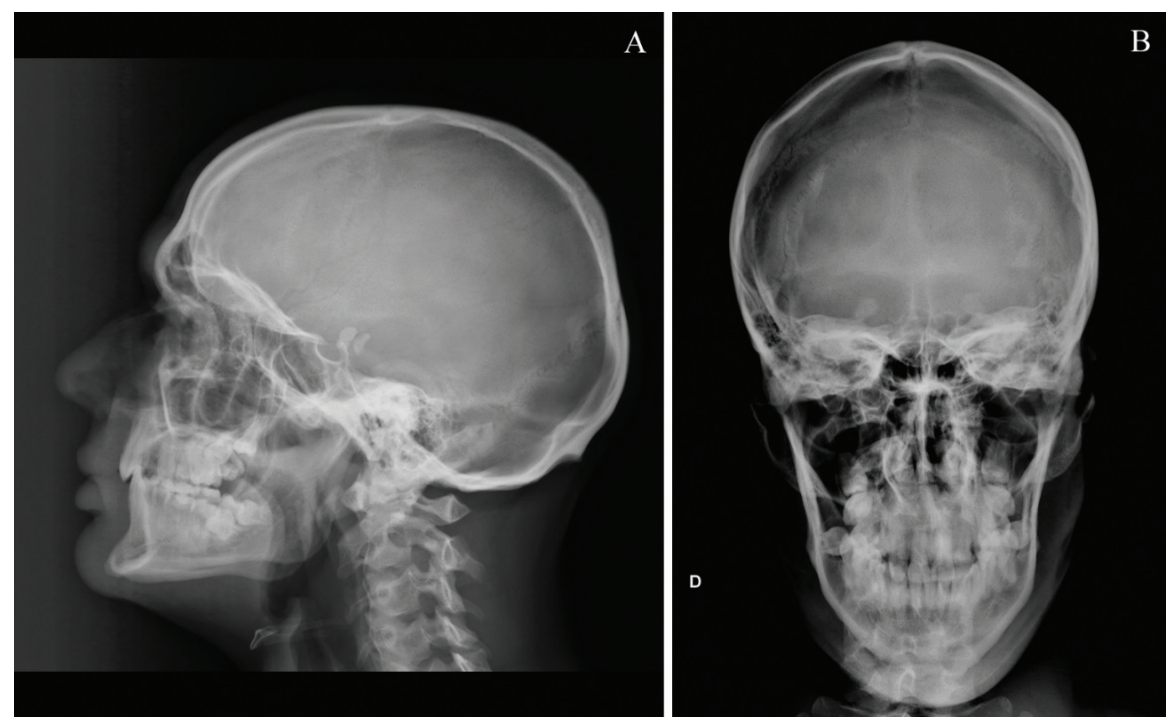

Figure 1: Conventional radiographs in anteroposterior $(A)$ and lateral $(B)$ views demonstrate typical bilateral, symmetrical, regular, parasellar radiodense foci corresponding to amygdalae calcifications. 


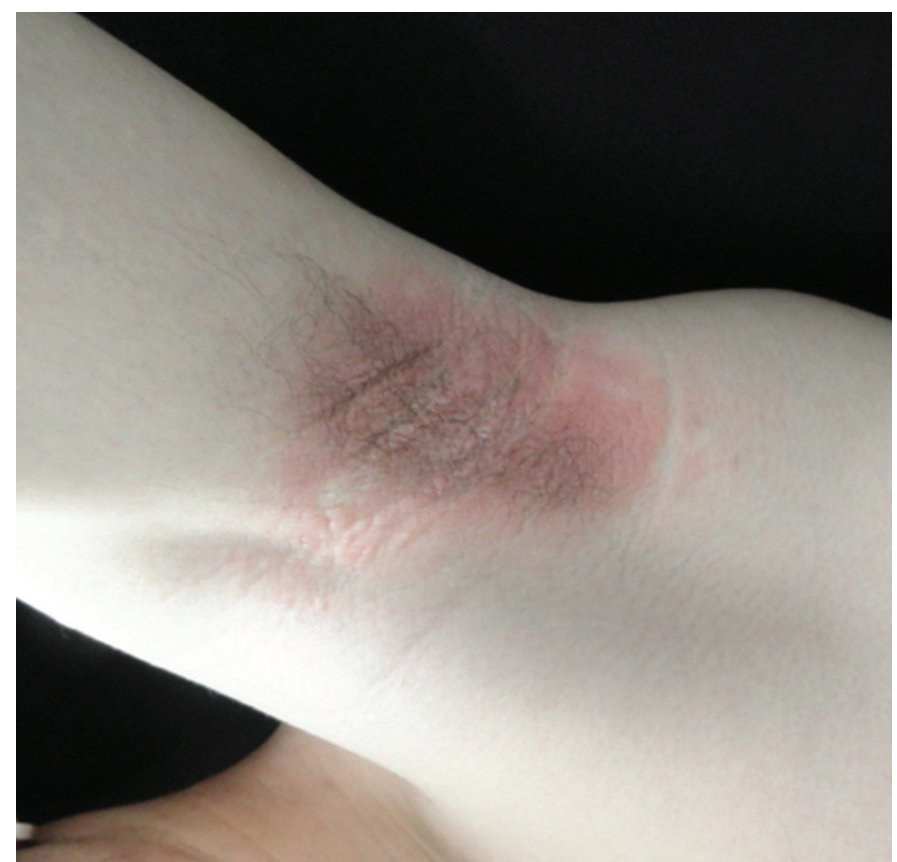

Figure 2: Axillary hyperkeratosis.

If the central nervous system is affected, a variety of neurological symptoms may be present, such as migraine, varying degrees of mental retardation, and seizures ${ }^{2}$. A characteristic finding on imaging studies is the presence of atypical intracranial calcifications, which occur mainly in the amygdala, hippocampus, parahippocampal gyrus, or even the striatum. Amygdala involvement is considered pathognomonic, being more prominent with longer disease duration ${ }^{3,5}$.

\section{REFERENCES}

1. Hamada T, McLean WH, Ramsay M, Ashton GH, Nanda A, Jenkins $\mathrm{T}$, et al. Lipoid proteinosis maps to 1q21 and is caused by mutations in the extracellular matrix protein 1 gene (ECM1). Hum Mol Genet. 2002;11(7):833-40. http://dx.doi. org/10.1093/hmg/11.7.833.

PMid:11929856

2. Claeys KG, Claes LR, Van Goethem JW, Sercu S, Merregaert J, Lambert $\mathrm{J}$, et al. Epilepsy and migraine in a patient with Urbach-Wiethe disease. Seizure. 2007;16(5):4658. http://dx.doi.org/10.1016/j. seizure.2007.02.014. PMid:17403608

3. Gonçalves FG, de Melo MB, de L Matos V, Barra FR, Figueroa RE. Amygdalae and striatum calcification in lipoid proteinosis. AJNR Am J Neuroradiol. 2010;31(1):88-90. http:// dx.doi.org/10.3174/ajnr.A1699. PMid:19696137

4. Dertlioğlu SB, Çalık M, Çiçek D. Demographic, clinical, and radiologic signs and treatment responses of lipoid proteinosis patients: a 10-case series from Sanlıurfa. Int J Dermatol. 2014;53(4):516-23. http://dx.doi. org/10.1111/ijd.12254. PMid:24320796

5. Appenzeller S, Chaloult E, Velho P, de Souza EM, Araújo VZ, Cendes F, et al. Amygdalae calcifications associated with disease duration in lipoid proteinosis. $J$ Neuroimaging. 2006;16(2):154-6. http://dx.doi.org/10.1111/j.15526569.2006.00018.x. PMid:16629738 